Dept. of Anat., Kyoto Prefectural Med. College (Director: Prof. Dr. H. NODA).

\title{
Phase Contrast Microscopic Observations on the Posterior Pituitary of Dog, with Special Reference to the Difference between the Neurosecretory Substance in the Hypothalamic Neurosecretory Nucleus and in the Posterior Lobe.
}

\author{
(Contributions to the Comparative Histology of the Hypothalamo- \\ hypophysial System. 33rd report.)
}

下垂体後葉（犬）飞和ける位相差顕微鏡所見，特飞神経分泌核に 招ける神経分泌物と後葉に括ける神経分泌物との差異について。

（視床下部下垂体系の比較組織学的研究。第 33 報.）

\section{Seiichiro TAKAHASHI 高 橋 誠一 郎。}

(Received April 27, 1957.)

In the previous report, the author has described the results of phase contrast microscopic observation on the neurosecretory substance and other intracellular structures in the fresh and fixed hypothalamic neurosecretory cells of a normal dog, comparing them with those findings observed in the fixed, stained sections by ordinary light microscope. In the present paper, the author reports on the phase contrast microscopic observations on the posterior lobe, a chief storage organ of the secretory materials produced by neurosecretory nuclei.

I. Material and method.

The same as is described in the previous paper.

\section{Observations and comments.}

\section{A. Observation with a fresh section.}

a) Neurosecretory granules.

Histologically the posterior lobe tissue can be divided into two phases'Verdichtungszone' (ROMEIS 1940), whose main component is a network of blood vessels and their accompanying lattice fibers, and ' $Z w$ ischenstreifen' (ROMEIS 1940), chiefly consisting of nerve fibers. In the section stained by GOMORI's C. H. P. method, the dark-blue stained neurosecretory granules display a distribution in accordance with 'Verdichtungszone', perivascularly aggregating densely. 
By the phase contrast microscopic observation of a fresh section, many granules as large as or a little beyond as large as those observed in the cytoplasm of a neurosecretory cell are observed in the 'Verdichtungszone' esp. perivascularly as in the case of GOMORI's staining (Fig. la). These

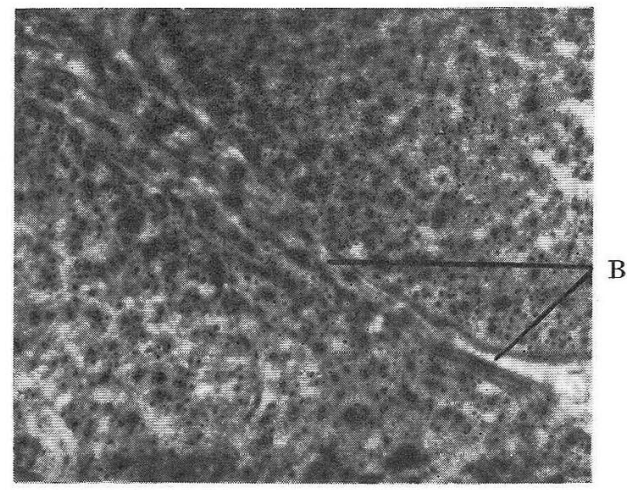

a

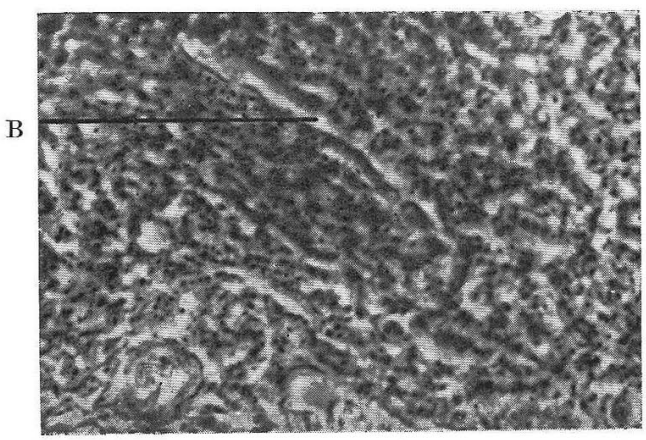

b

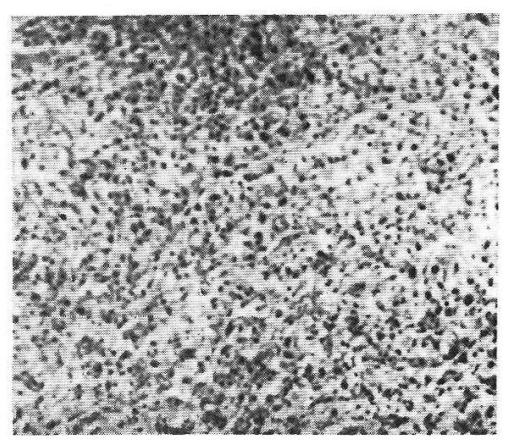

c

Fig. 1. Phase contrast microphotographs of 'Verdichtungszone' in the posterior lobe of dog, showing many spherical neurosecretory granules around the blood vessel. a The fresh section. $\times 500$. b The section fixed with ZENKER's fluid. Paraffin, $4 \mu, \times 400$. c The section fixed with alcohol. Paraffin, $4 \mu, \times 520$. P. M. $B$ blood vessel.

granules are identified with gomoriphil neurosecretory granules for their optical quality, their distribution and for the fact that, as is to be described in the next report, they reveal a marked decrease in the dehydrated condition. The relationship between these granules and nerve fibers of the hypothalamo-hypophysial tract could not be clarified by phase contrast microscopy. 


\section{b) Pituicytes.}

In the fresh section, pituicytes are, in dark contrast phase, observed in multifarious forms and shapes such as circular, oval, long fusiform, piriform, triangular etc., the nucleus occupying a greater portion of the cell body and the cytoplasm being observed only as a thin membrane surrounding the nucleus. The nucleus assumes a dark or a little lighter greyish dark tone. Some of them look homogeneous, and some are observed to have large granular, nuclear substances within themselves. In the phase contrast microscopic observation of the fresh section, such granules as observed in the neurosecretory cell could not be found in the cytoplasm of a pituicyte (Fig. 2a).

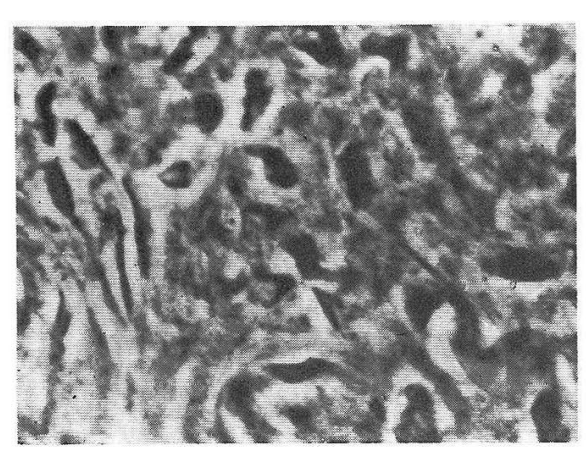

a

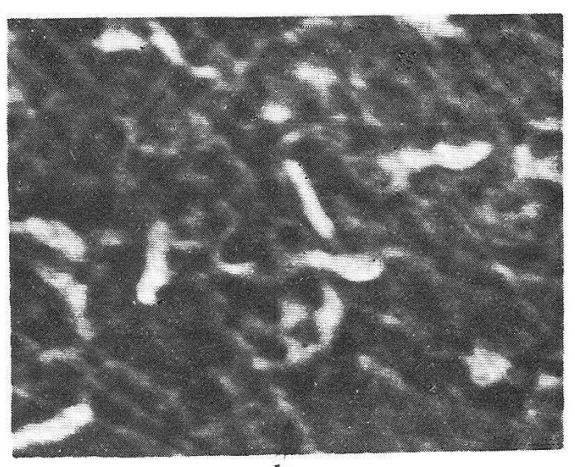

b

Fig. 2. Phase contrast microphotographs of fresh pituicytes in the posterior lobe of dog. a Pituicytes and their processes noted darkly. P. M., $\times 550$. b Pituicytes and their processes noted brightly in the dark background. N. M., $\times 500$.

The process of a pituicyte is unipolar, bipolar or multipolar, looking dark or greyish dark. Pituicyte fibers are better observed in bright contrast phase. When observed in bright contrast phase, pituicytes and their fibers stand in bright relief on a dark background, the inside of the nucleus appearing almost homogeneous. The relatively thick main process cannot be traced along for a long distance from cell-body to its ending, the inside of processes looks structureless, and their length is variously long or short, and on the way of its course, winding, meandering, wavy or arched form and thickening of various forms and shapes are observed (Fig. 2b).

\section{B. Observation with sections fixed with ZENKER's fluid, BOUIN's fluid, and formalin.}

The observations on the posterior lobe with the section fixed by any of the above-mentioned methods are nearly the same with those in the 
fresh section as to both neurosecretory granules and pituicytes (Fig. 1b).

\section{Observation with a section fixed with alcohol.}

Phase contrast microscopic findings in the posterior lobe with the section fixed with alcohol were very peculiar.

As is already known, in case of the section fixed with alcohol to which GOMORI's staining has been applied, no gomoriphil granules are stained up either in hypothalamic neurosecretory nucleus or in the posterior lobe. But, if GOMORI's staining is applied to the section that has been re-fixed with ZENKER's fluid (IMOTO 1955) or with BOUIN's fluid (SLOPER 1955) before decerating (paraffin removing), some gomoriphil granules are found, their GOMORI-stainability being recovered, in the posterior lobe, while, in the hypothalamic neurosecretory cell, no gomoriphil granules are stained out as it was before.

The author's phase contrast microscopic observations have proved that, in the non-fixed section and in the sections fixed with ZENKER's fluid, BOUIN's fluid, and formalin, the findings are in accord with those obtained by GOMORI's staining, while, in the section fixed with alcohol, the result agrees with that obtained by GOMORI's staining as to hypothalamic nucleus, but it does not agree with that of GOMORI's staining concerning the posterior lobe. That is, by phase contrast microscopy, in the section fixed with alcohol, no neurosecretory granules are observed in the hypothalamic neurosecretory cell as in the case of GOMOGI's staining, while, in the posterior lobe, they are observed (Fig. 1c). And that they are observed in the section fixed with alcohol alone without any need of re-fixation with BOUIN's or ZENKER's fluid is an important point that differs from the case by GOMORI's staining. In other words, the neurosecretory granules in the neurosecretory cell lose their granular form by the action of alcohol, while those in the posteior lobe, merely changing their stainability, lose their gomoriphil quality with no loss of their form, which means that the neurosecretory granules in both regions vary their chemical nature, esp. in all probability, the conditions of combination with lipid, and which, at the same time, might be considered to confirm the report of HILD and ZETLER (1954) that the amount of hormone contained in the posterior lobe remains unchanged even in the condition deprived of gomoriphil granules by alcohol fixation.

\section{Summary.}

The posterior pituitary of normal dog was observed by phase contrast microscopy, and the following results were obtained:

1. Many granules are observed in the so-called 'Verdichtungszone' of the posterior pituitary esp. perivascularly. These granules are identified 
with the neurosecretory granules because of a close resemblance of their size, shape and distribution to those of gomoriphil granules in the fixed and stained section after GOMORI's method.

2. No like granules are observed in the cytoplasm of a pituicyte.

3. These findings are about the same in a fresh section as in a fixed section other than with alcohol.

4. By the phase contrast method, neurosecretory granules are not observed, in the section fixed with alcohol, in hypothalamic nucleus, but they are observed in the posterior lobe. This result has nothing to do with re-fixation or no re-fixation of the section with ZENKER's or BOUIN's fluid. It leads us to the conclusion that there is a difference of chemical nature esp. of the conditions of combination with lipid between the neurosecretory substance in hypothalamic neurosecretory nucleus and that in the posterior lobe.

\section{内 容 自 抄.}

前報に引き続き, 正常犬の後葉について位相差顕微鏡観察を行った.

無固定凍結切片の位相差観察によっても, Gomori 染色標本に招けると同 様に 'Verdichtungszone' の主として血管周囲に, 多数の, 神経分泌細胞内 そ認められるものと同大或はそれらょりも稍々大形の顆粒が見出され，そ の分布状態及び次報に括いて記載するごとく渴状態下に拾けるとの激減の 所見から，それらは Gomori 染色標本に招ける Gomori 好性顆粒，即ち神 経分泌顆粒と同定される。後葉膠細胞 (pituicyte) は多種多様の形態を示 し，細胞体の大部分は核によって占められ，細胞質はとの周囲に僅かに膜 状飞認められる。神経分泌細胞に怙けるごとき細胞質内の顆粒は認められ ない，乫起は単極，双極或は多極であり，全長を辿ることはできないが， 内部は無構造飞見元，経過中，屈曲，蛇行状，波状，弓状等の走行或は部 分的肥厚を示す，以上の所見は Zenker 氏液，Bouin 氏液或は formalin で 固定した paraffin 切片でも大体同様に認められる。

一般に alcohol で固定した切片では神経分泌核でも後葉でも Gomori 好 性顆粒は染出されないが，脱パラ前とその切片をZenker 氏液又は Bouin 氏液で再固定すると，神経分泌核には依然として Gomori 好性顆粒が認め られないが，後葉には再固定によって Gomori 好性を回復した顆粒が出現 することが知られている．然るに alcohol 固定切片を位相差法で観察した 結果，この場合にも神経分泌核には分泌顆粒を見出し得ないが，後葉には 分泌顆粒が失われていないことが見出された。 しかもこの場合は単に alcohol で固定したのみの切片について分泌顆粒が認められ，再固定の有無 そは関しない. 即ち alcohol 固定切片での位相差顕微鏡所見は神経分泌核 
では Gomori 染色所見と一致するが, 後葉では全く異るのであり，このこ とから alcohol 固定の後葉に扮いて Gomori 好性顆粒が失われていること は分泌顆粒そのものの娈失を意味するのではなく，分泌顆粒の染色性の変 化，換言すれば Gomori 好性の哀失に基ずく所見であることがわかる．ま たこのことから神経分泌顆粒が等しく糖脂質蛋白複合体であるとしても， 視床下部々後葉の両部位ではその構造, 恐らくは Gomori 染色に括ける呈 色物質と脂質の結合状態が異っていることが推定されるとともに，alcohol によって Gomori 好性が失われた状態に括いても後葉の後葉ホルモン検定 值が不変に止まるという Hild と Zetlerの報告が裏付けられる.

\section{References.}

Hild, W. a. G. Zetler : Pubbl. Staz. Zool. Napoli. 24, Suppl. (1954). P. 15. Romeis, B.: Möllendorffs Handbuch der mikroskopischen Anatomie des Menschen. Innersekretorische Drüsen. II. Hypophyse. 1940. - Sloper, J. C. : Anat. Rec. 89 (1955). P. 301. - Imoto, T.: Unpublished. - Takahashi, S.: Arch. hist. jap. 12 (1957). P. 297. 